\title{
RISK PERCEPTION AND EYE-TRACKING: A RESEARCH ON UNIVERSITY STUDENTS
}

\author{
DOI: 10.17261/Pressacademia.2020.1323 \\ RJBM- V.7-ISS.4-2020(6)-p.268-276
}

\section{Murat Cinko ${ }^{1}$, Beril Durmus², Emin Avci3}

${ }^{1}$ Marmara University, Department of Business Administration, Istanbul, Turkey. mcinko@marmara.edu.tr, ORCID: 0000-0001-8560-7482

${ }^{2}$ Marmara University, Department of Business Administration, Istanbul, Turkey. beril@marmara.edu.tr, ORCID: 0000-0002-9679-9608

${ }^{3}$ Marmara University, Department of Business Administration, Istanbul, Turkey. eavci@marmara.edu.tr, ORCID: 0000-0003-3172-897X

Date Received: October 29, 2020 Date Accepted: December 14, 2020

To cite this document

Çinko,M., Durmuş, B., Avcı, E. (2020). Risk perception and eye-tracking: A research on university students. Research Journal of Business and Management (RJBM), V7(4), p.268-276.

Permanent link to this document: http://doi.org/10.17261/Pressacademia.2020.1323

Copyright: Published by PressAcademia and limited licensed re-use rights only.

\section{ABSTRACT}

Purpose- The purpose of this study is to analyze the risk perception of university students by the use of eye-tracking technique and reveal the relation between risk perception, financial literacy and financial behavior.

Methodology- In order to measure risk perception, financial literacy financial behavior and demographics of participants four different questionnaires were offered. To measure risk perception, participants were asked to make a choice between safe money and lottery game. While the participants were answering the questions, their eye movements were recorded via an eye-tracking device. The data was analyzed by Chi square test, Fisher's test, Sign Test and Mann-Whitney U test.

Findings- The risk perception is not subject to change although switch to safe money option has been observed at early stages of games when the amount of safe money is increasing. There is a difference in gaze time under different scenarios and risk attitudes. No relation has found between eye movements, financial literacy and behavior.

Conclusion- The amount of safe money has an effect on participants' choice on the lottery/safe money option; in spade of the finding on differences in fixation time under different scenarios and risk attitudes, no relation could be documented between eye movements, financial perception, financial behavior and financial literacy.

Keywords: Risk perception, financial literacy, financial behaviour, eye-tracking, decision making JEL Codes: D81, D83, C91

\section{RISK ALGISI VE GÖZ-TAKIBi: ÜNIVERSITE ÖĞRENCILERI ÜZERINDE BIR ARAŞTIRMA}

\section{ÖZET}

Amaç- Bu çalışmanın amacı göz-takip tekniği ile üniversite öğrencilerinin risk algılarını analiz ederek, risk algısı, finansal okur-yazarlık ve finansal davranış arasındaki ilişkiyi ortaya koymaktır.

Yöntem - Katılımcıların risk algısı, finansal okur-yazarlık, finansal davranış ve demografik özelliklerinin ölçmek üzere 4 farklı anket uygulanmıştır. Risk algısını ölçmek için katılımcıların garanti para ile şans oyunu arasında tercih yapmaları istenmiştir. Katılımcılar sorulara cevap verirlerken, göz hareketleri göz takip cihazıyla kayıt altına alınmıştır. Elde edilen veri Ki kare testi, Fisher's testi, İşaret testi ve Mann-Whitney U testi ile analiz edilmiştir.

Bulgular- Risk algısının değişmemesine rağmen garanti para seçeneğine oyunun daha erken aşamada geçiş olduğu tespit edilmiştir. Farklı senaryolar ve risk algılarında seçeneklere bakma sürelerinde farklılıklar bulunmuştur. Risk algısı, finansal okur-yazarlık ve finansal davranış arasında ilişki tespit edilememiştir.

Sonuç- Garanti para miktarının katııımcıların oyun/garanti para tercihlerini etkilediği; katılııların kimi senaryolar ve risk tutumları altında seçeneğe bakma süreleri değişmekle beraber göz hareketleri ile katılımcı finansal okur-yazarlık, finansal tutum ve finansal davranış arasında anlamlı bir ilişki olmadığı sonucuna ulaşılımıstır.

Anahtar Kelimeler: Risk algısı, finansal okur-yazarlık, finansal davranış, göz takibi, karar verme JEL Kodları: D81, D83, C91 


\section{GiRiş}

İnsanlar ne ister? Ne istediğimize nasıl karar veririz? Bu kararlar ne kadar sürede alınır? Bu soruların hepsinin "zamana bağlı, biraz sürer" gibi cevapları olmaktadır. Nörobilim aslında bu ve benzeri soruların hiç de düşünüldüğü gibi uzun sürelerde cevaplanmadığını, aksine saniyenin yüzde beşinde veya daha az sürede beyinde oluşan kimyasal reaksiyonlar sonucunda cevabın verildiğini ortaya koymaktadır.

Risk taşıyan durumlarda karar vermek de herhangi bir karar gibi kimyasal reaksiyonlar sonuncunda olmaktadır. Ancak, her bireyin verdiği karar, karşılaşılan olay aynı bile olsa farklı olabilmektedir. Dolayısıyla soru: Temel karar alma mekanizmaları aynı bile olsa acaba insanların risk alma davranışları neden farklılık göstermektedir? Örneğin \%50 kazanma olasılığının olduğu bir oyunda bireyler oyun oynamayı mı yoksa kendilerine sunulacak garanti parayı mı tercih ederler? Garanti para miktarı veya kazanma olasılığı, sunulan oyundaki parasal büyüklük insanların kararlarını etkiler mi? Finansal bilgi düzeyi ve demografik yapı, karar verme de etkili midir?

Bu ve benzeri sorulara kesin yanıtlar vermek ise gerek beynin karmaşık işleyişi nedeniyle gerekse de kişisel farklılıklar nedeniyle mümkün olamamaktadır. Ancak, hala kara bir kutu olmasına rağmen, teknolojik ilerlemeler, beynin belirli bölgelerinin belirli davranışları sergilemek veya kararlar vermek için milisaniyelerde işlemler yaptığını göstermektedir. Beyin tarafından gerçekleştirilen işlemlerin dışarıdan anlaşılması çoğunlukla imkansız olmakla beraber, gene teknolojik gelişmeler sayesinde, göz ve göz bebeği hareketlerinin veya göz bebeği odaklanmasının bireylerin karar verme süreçlerini yansıttığı düşünülmektedir.

Bu çalışmanın 2 temel amacı bulunmaktadır. Ilk olarak farklı durumlar altında bireylerin karar verme aşamasında göz hareketlerinin takip edilmesi ve parasal büyüklükler değiştiğinde göz reaksiyonlarının farklılaşıp farklılaşmadığının tespit edilmesidir. İkinci olarak ise bireylerin finansal okuryazarlık düzeyleri ve demografik yapılarının risk algısında farklılık yaratıp yaratmadığı veya ilişkili olup olmadığının belirlenmesidir.

Çalışmanın ikinci bölümünde konuya ilişkin literatür incelenecek; üçüncü bölümünde uygulanan metot anlatılacak; dördüncü bölümünde bulgular sunulacaktır. Son bölümde ise bulgular değerlendirilecektir.

\section{2. İGILI LITERATÜR}

Bireyin karar verme süreçlerini ve bu süreçleri açıklamaya çalışan teorileri ekonomi, psikoloji hatta tıp gibi farklı disiplinler altında incelemek mümkündür. Bireylerin karar verme süreçleri, risk altında karar verme, karar vermeyi etkileyen bireysel-çevreseltoplumsal unsurlar ve benzeri araştırma konuları hem psikoloji hem de ekonomi bilimleri altında incelenmektedir. Son yıllarda ise karar vermenin biyolojik süreçleri tıp alanı altında incelenmektedir. Bu bağlamda konuya ilişkin literatür oldukça geniştir. Bu bölüm altında, literatüre girmiş olan çeşitli eserlerden, bu çalışmanın amaçlarına uygun olarak risk alma davranışlarını (riske duyarlılık) inceleyen çalışmalara yer verilecektir.

Bu çalışma kapsamında değerlendirilebilecek literatür incelendiğinde bazı araştırmacıların risk algısının öğrenilen ve çevresel şartlardan etkilendiğini ifade ettiği, bazı araştırmacıların ise risk algısının biyolojik faktörler ile açıklanabileceğine yönelik çalışmalar yaptıkları görülmektedir. Risk konusunda yapılan çalışmalarda bireylerin davranışlarını ölçmek için çeşitli teknikler kullanılmaktadır. Bu teknikler arasında Likert ölçeğini kullanarak bireylerin belirli durumlarda kendilerini nasıl özdeşleştirdikleri, basit piyangolar kullanılarak ne kadar risk alabilecekleri ve laboratuvar deneyleri sayılabilir. Ölçüm tekniklerinin beraber kullanılarak veya test tekrar test kullanılarak cevaplayıcıların güvenilirliği veya ölçüm aracının güvenilirliği test edilmektedir.

Riske duyarlıı̆ı (aversion) ölçmek için kullanılan yaklaşımları yatırım portföyü (investment portfolio) , piyango (veya oyun) tercihi (lottery choice) ve fiyatlama (pricing task) olarak sınıflandırmak mümkündür. Yatırım portföyü ve piyango tercihi yaklaşımlarında katılımcıların tekli veya çoklu yatırım (piyango) alternatifleri arasından tercihler yapmaları beklenirken, fiyatlama yaklaşımında teklif edilen bir yatırım veya piyangoya katılımcıların ne kadar ödemek isteyecekleri araştırılmaktadır (Holt \& Laury, 2014).

Bu çalışmanın konusu kapsamında değerlendirilebilecek araştırmalardan Dohmen, vd. (2010) tarafından Almanya'da yaşayan 17 yaş ve üstü 1012 bireyin evinde görüşmeler yapılmış; 500 birey indirimli deney, 452 birey ise piyango oyununa katılmışlardır. Deneylerde ve piyango oyununda bilişsel becerileri yüksek olan katılımcıların daha fazla risk alma eğiliminde olduğu ve daha fazla sabır gösterdiklerini bulmuşlardır. Diğer bir çalışmada, Dohmen, vd. (2011) 450 katılımcı ile anket yöntemini kullanarak genel risk algısı ve araba kullanma, finansal konular, spor ve eğlence, sağlık ve kariyer alanlarındaki (beş alt başlık) risk algısını ölçmüşlerdir. Kadınların bütün alt başlıklarda daha az risk aldıklarını bulmuşlardır. Genel olarak bireyler orta noktada yığılırken, çok küçük bir kısmı hiç risk almayanlardan ve en üst düzeyde risk alanlardan oluşmaktadır. Bireylerin demografik özelliklerine göre yaş, cinsiyet, boy ve aile geçmişi incelendiğinde ise yaşlıların ve kadınların daha düşük risk düzeyini tercih ettikleri görülmüştür. Ailenin eğitim durumunun risk alma tutumunu pozitif etkilediğini ve uzun boylu bireylerin erkeklerde de kadınlarda da daha fazla risk alma eğiliminde olduğunu göstermiştir. Çalışmanın ikinci kısmında \%50 kazanma ihtimali olan bir oyun katılımı ve garanti para 
seçenekleri katılımcılara sorulmuştur. Beklenen değerin altında garanti parayı tercih edenler riskten kaçınan (\%78), beklenen değerde garanti parayı alanlar risk doğal (\%13) ve beklenen değerin üstünde oyunu tercih edenler ise risk seven (\%9) olarak sınıflanmıştır. Bu kategorizasyon ile ankette verilen cevaplarla risk algısının paralel olduğunu tespit etmişlerdir.

Benzer bir çalışmada, Lönnqvist, vd. (2015) Beş Faktörlü Kişilik anketi yapılan 945 öğrenciden 232'si laboratuvar deneylerine tabi tutulmuş ve grubun risk düzeyleri belirlenmeye çalışılmıştır. Deneyler esnasında ilk olarak Berg vd (1995) tarafından önerilen güvenoyunu oynatılmış, sonrasında Holt ve Laury (2002) tarafından önerilen piyango oyunu oynatılmış ve son olarak katılımcıların risk tutumları Dohmen vd (2011) tarafından önerilen sorular kullanılarak ölçülmüştür. Bir yıl sonra toplam 44 katılımcı tekrar deneylere katılmaları için davet edilmiştir. Çalışmanın sonucunda iki deneydeki risk tutumlarının korelasyonunun olmadığı, soru sorarak elde edilen risk tutumu ile bireysel güvenme tutumunun test tekrar test güvenilirliğinin yüksek olduğunu, ancak piyango oyununda bunun gerçekleşmediğini, beş faktörlü kişilik envanteri ile risk sorularından elde edilen sonuçların korelasyonunun olduğunun fakat piyango oyununda bunun olmadığını bulmuşlardır. Sonuç olarak Berg vd (1995) ile Dohmen vd (2011) önerdiği risk algısı ölçüm tekniklerinin paralel sonuçlar verdiğini ancak piyango deneyinde paralel sonuçlar elde edilemediğini göstermiştir. Farklı yaklaşımların bir arada kullanıldığı diğer bir çalışmada, Crosetto ve Filippin (2016) dört farklı deney ve iki farklı anket kullanarak risk algısını ölçmeye çalışmışlardır. Çalışmaya 350 lisans öğrencisi katılmış ve 12 deney yapılmıştır. Her bir öğrenci bir adet deneye katılmış ve deneyler başlamadan önce anket sorularını ve demografik değişkenleri cevaplamışlardır. Dört deneydeki erkek ve kadınların risk algıları karşılaştırılmış ve farklı sonuçlar bulunmuştur. İki deneyde erkekler kadınlardan daha fazla risk alırken, diğer iki deneyde erkekler ile kadınlar arasında fark bulunamamıştır. Anket sorularına verilen cevapların korelasyon analizi ile benzer olduğu bulunmuştur. Benzer çalışmalardan, Deck vd (2013) dört deney ve anket içeren çalışmalarına ağırlığı lisans öğrencilerinden oluşan 203 kişi katılmıştır. Çalışmada anket soruları ile deneylerin paralel sonuçlar verip vermediği araştırılmıştır. Deneyler ile anket sonuçlarının paralel sonuçlar vermediğini bulmuşlardır. Anket cevaplarından finansal risk konusu ile deneylerin arasında yapılan regresyon sonucunda cevapların paralellik gösterdiğini ancak diğer alt başlıklarda yeterince açıklayıcı olmadığını ifade etmişlerdir.

Kimi çalışmalar ise katılımcıların biyolojik farklııklarının risk alma davranışlarındaki etkilerini incelemişlerdir. Bu çalışmalardan Dreber vd. (2010) briç turnuvasına katılmış olan oyuncular ile oyun oynarken risk alıp almadıklarını incelediğinde risk alma davranışının kadın ve erkeklerde farklı olmadığını bulmuşlardır. Katılımcıların DNA örnekleri toplanmış ve genleri incelenmiştir. Bulgular dopamin geni olan D4 ile risk alma duygusunun pozitif ilişkili olduğunu göstermiştir. Daha sonra katılımcıların risk algılarını anket yöntemi ile tespit edilmeye çalışılmıştır. Ayrıca, katılımcılara yatırım oyunu oynatılmıştır. Kadın ve erkeklerin yatırım ortalama değerleri karşılaştırıımış ve kadınların daha az miktarda para yatırdıkları bulunmuştur. Katılımcıların Dopamin geni kromozom sayıları ile regresyon analizi yapılmış ve sonuçlar gen sayısının ekonomik risk alma üzerinde etkili olduğunu göstermiştir. Hormonların risk alma davranışındaki etkisinin incelendiği diğer bir çalışmada Oran ve Akyatan (2012) üniversite öğrencisi katılımcıların öncelikle risk alma davranışları (yatırım, hisse senedi, kariyer ve maceraperestlik alanlarında) anket yöntemiyle ölçülmüş, devamında ise sabah ve öğleden sonra alınan örneklerle katılımcıların hormon seviyeleri analiz edilmiştir. Her ne kadar farklı risk alma alanları için farklı sonuçlara ulaşılsa da, kortizol ve testestoron hormonlarının erkeklerde risk alma davranışını daha çok etkilediği bulunmuştur. Ayrıca, hormonlar ile risk alma davranışı arasındaki ilişkinin öğleden sonraları daha güçlü olduğu tespit edilmiştir. Biyolojik farklılıkların risk alma davranışı üzerindeki etkilerinin incelendiği diğer bir çalışmada, Dreber ve Hoffman (2007) işaret parmağının ve yüzük parmağının uzunluklarının oranı ile risk alma arasında ilişkiyi araştırmışlardır. Biyolojik olarak işaret parmağı ile yüzük parmağının oranı östrojen ile pozitif, testosteron ile negatif ilişkili olduğu varsayımından yola çıkılan çalışmada,146 öğrenciye yaklaşık $250 \$$ verilerek yatırım yapmaları istenmiştir. Yapılan yatırımın başarılı olma ihtimali \%50 olarak ifade edilmiş ve başarılı olması durumunda yatırılan miktarın 2,5 katı kazanılacağı diğer durumda ise yatıılan para sıfırlanacağı bilgisi verilmiştir. Kadınların yatırım miktarının erkeklere göre daha az miktarda olduğu ve kadınların erkeklere göre daha az risk aldıklarını bulunmuştur; ancak, yüzük parmağı ile işaret parmağı oranının risk algısı üzerinde anlamlı bir etkisinin olmadığını tespit etmişlerdir.

Sarin ve Wieland (2016) yaptıkları çalışmada kadınlar ile erkeklerin riskten kaçınma davranışlarının belirsizlik altında nasıl olduğunu ve farklılık olup olmadığını araştırmışlardır. Olasılığı belli olan oyunlarda kadınların erkeklere göre daha fazla riskten kaçındığını gösteren birçok çalışmanın olduğu, aynı durumun belirsizlik altında olup olmadığını araştırmışlardır. 106 katılımcı ile çevirimiçi gerçekleştirilen çalışmada 101 katılımcının cevapları değerlendirilmiştir. Katılımcılara farklı kazanma olasılığı olan oyunlar (fiyatlama oyunu) sunulmuş ve katılımcıların demografik özellikleri sorularak cevaplar toplanmıştır. Regresyon analizleri sonucunda erkeklerin kadınlara göre oyun almak için ödedikleri paranın 2,2 katı olduğunu tespit edilmiştir. Araştırmacılar Altın Küre ve Amerikan Ulusal Futbol Ligi'ni kimin kazanacağı ile ilgili katılımcıların bireysel olasılıklarının devreye girdiği ikinci bir çalışma yapmışlardır. 185 kişinin katıldığı ikinci çalışmada belirsizlik ortamı bulunmaktadır ve katılımcılar kimin kazanacağını kendi tecrübelerine göre belirlemektedirler. Yapılan testlerde belirsizlik olan durumlarda bireylerin belirledikleri olasılıklar üzerinden kadınlar ve erkekler arasında riskten kaçınmada fark olmadığı tespit edilmiştir. Çocuklar ve gençler üzerine yürütülen çalışmada Sutter vd (2013) yaşları 10 ile 18 arasında değişen 661 çocuk ve genç ile deney yaparak risk algılarını ölçmüşlerdir. Bulgular, 
demografik değişkenler ile yapılan regresyon analizinde kızların erkeklerden daha fazla riskten kaçındığını ve yaşın etkili olmadığını bulmuşlardır. Belirsizlik durumunda ise cinsiyet ve yaş değişkenlerinin farklılık yaratmadığını tespit etmişlerdir. İleri tarihli ödemelerde miktar arttıkça ileri tarihli ödemelerin seçildiği bulunmuş; bu da çocukların sabırlı olduğu ve riskten kaçınanlarda sabırlı olma davranışının daha fazla olduğunu tespit etmişlerdir. Risk ve belirsizlik kavramları çerçevesinde yapılan uluslararası bir çalışmada Vieider vd., (2015) 30 ülkede 2939 bireyin katılımı ile farklı boyutları ile risk ve belirsizlik ilişkisini ölçülmeye çalışılmıştır. 44 farklı piyango oyunu oynattırımıştır, bu oyunlar kazanma veya kaybetme mantığının dışında bireyin farklı alanlarda (spor, sağlık veya sosyal alanlar gibi) kendini değerlendirme sorularını da içermektedir. Illk olarak oyunlar ile bireylerin risk ve belirsizlik altında karar vermeleri istenmiştir. Sonraki sekiz oyunda belirsizlik altında oyun ya da garanti parayı tercih etmesi istenmiştir. Sonraki 13 oyun ise belirli bir olasılık altında kaybetmeme mantığı üzerine kurulmuştur. Kalan son dokuz oyun ise belirsizlik altında aynı şekilde oynatılmıştır. Anket kullanılarak bireylerin kendilerini değerlendirmeleri istenmiş ayrıca demografik bilgileri toplanmıştır. Ülkelerin makroekonomik göstergeleri ile risk ve belirsizlik altında karar verme mekanizmaları anlaşılmaya çalışılmıştır. Bulgular İngiltere hariç (araştırmacı örneklemeden kaynaklanabileceğini düşünmekte) batı ülkelerinin riskten kaçındığını Etiyopya, Peru ve Nikaragura gibi ülkelerin ise riski sevdiklerini ifade etmektedir. Olasılığın az olduğu yerlerde daha riskli davranış gösterilirken, olasılık arttıkça riskten kaçınmanın arttığını gözlemlemişlerdir. Anket sorularından elde edilen finansal risk değerlendirmesi ile oyunların sonucunda verilen kararların pozitif ilişkili olduğunu tespit etmişlerdir. Kişi başına milli gelir ile risk algısı arasında güçlü bir ilişki tespit edilmiştir. Kişi başı geliri düşük olan ülkelerde belirsizliğin daha belirleyici olduğunu bulmuşlardır. Batılı ülkelerin riskten kaçındığına dair bulgu Harrison vd. (2007) tarafından da Danimarka örneğinde teyit edilmiştir. Bu çalışmada Holt and Laury (2002) tarafından önerilen deneyi kullanarak Danimarka'lıların risk algısını ölçmüşlerdir. Çalışmada Danimarka halkını temsil edebilecek 19 ile 75 yaş arasındaki 253 kişi rastgele seçilmiştir. ilk olarak çalışmaya katılanların demografik özelliklerini, ikinci aşamada dört adet risk kaçınma görevini, üçüncü aşamada altı adet indirimli görevi ve son aşamada ise finansal piyasalar ile ilgili bilgileri, gelecekteki ekonomik durumlarını belirtecekleri anket çalışması yapılmıştır. Çalışmanın sonucunda ortalama bir Danimarkalı'nın riskten kaçınma davranışı sergilediğini bulmuşlardır. 40-50 yaş grubundaki Danimarkalı'ların diğer yaş gruplarındakilere göre daha fazla riski sevdiklerini bulmuşlardır. Eğitim durumu ile risk algısı arasında pozitif ilişki olduğunu ancak risk algısının cinsiyete göre değişmediğini tespit etmişlerdir.

Bireylerin karar verme aşamasın vücutlarında çeşitli kimyasal ve fiziksel reaksiyonlar gerçekleştiği, fiziksel reaksiyonların büyük bir kısmının ise göz hareketleri şeklinde ortaya çıktığı gözlemlenebilmektedir. Göz hareketleri ile karar verme arasındaki ilişki birçok çalışmanın konusu olmuştur. Davranışsal nörobilimin (behavioral neuroscience) karar sürecinde beynin alternatiflere değerler atadığını ve bu değerler üzerinden karar verdiği hususunda birleştiğini ifade eden Krajbich, vd. (2010), göz odaklanması ile karar verme arasında ilişki olduğu ve görsel odaklanma ile değer tabanlı karar verme arasında neden sonuç ilişkisi olabileceği yönünde bulgulara ulaşmışlardır. Franco-Watkins ve Johnson (2011) görsel dikkat ve göz hareketlerinin örtüştüğünün kabulü halinde dikkatteki değişimin göz hareketlerinin değişimi ile tespit edilebileceğini ileri sürmüşlerdir. Literatürde bu konuya ilişkin oldukça fazla çalışma bulunmakta olup, bu kısımda araştırma alanımız içine giren çalışmalara yer verilecektir; ancak alandaki çalışmaların gelişimi Orquin ve Mueller Loose, (2013) tarafından hazırlanan derleme niteliğindeki çalışmadan takip edilebilir.

Riskli durumlarda karar verme süreçlerinin göz hareketleri incelenerek araştırıldığı çalışmalardan, Glöckner ve Herbold (2011) 18 Bonn Üniversite öğrencisiyle yürüttükleri çalışmada öğrencilerden farklı olasılıklarda kazanma (kaybetme) şansı veren tercihler yapmalarını talep etmişlerdir. Öğrencilerin karar verme süreçlerindeki göz hareketleri kayıt altına alınmıştır. Bulgular miktarlar ve olasılıkların yakın olduğu oyunlarda karar verme sürelerinin uzun olduğu, katılımcıların her bir bilgi alanına ortalama 4 kere odaklandıkları, odaklanma sürelerinin kısa olduğu, bilgi alanlarına odaklanma sürelerinin farklı olduğunu göstermiştir. Çoğunluğu öğrenci olan 24 kişi üzerinde yürüttülen diğer bir çalışmada Fiedler ve Glöckner (2012) katılımcılara farklı şekilde yapılandırılmış 50 'şer soru (oyun) sormuşlardır. Bulgular beklenen değerin farkının yükseldiği durumlarda, katılımcıların oyun oynama eğiliminin yükseldiğini; oyunlar arası beklenen değer farkının azaldığı durumlarda katılımcıların karar verme sürelerinin uzadığı ve göz odaklanma sayılarının arttığı, katıımcıların öncelikle olasılıklara odaklandıklarını göstermiştir. Benzer bir çalışmada, Stewart, vd. (2016) 48 üniversite katılımcısının dahil olduğu çalışmada göz hareketleri ile karar verme arasındaki ilişkiyi incelemişlerdir. Katılımcıların göz hareketleri kayıt altına alınırken, çeşitli olasılıklarda kazanma (kaybetme) şansı tanıyan oyunlar arasında tercih yapmaları istenmiştir. Çalışmanın bulguları katılımcıların olasılıklar ve miktara aynı düzeyde odaklandıklarını, ancak seçim yapma aşamasında odaklanmanın daha fazla olduğunu ve en çok odaklandıkları seçeneği tercih ettiklerini göstermiştir.

Görsel dikkatin birey kararlarında ve duygusal tecrübenin şekillendirilmesinde etkili olduğu varsayımından hareketle Bault, vd. (2016), 20 yetişkin katılımcıyla pişmanlık ve piyango oyunu kararları arasındaki ilişkiyi göz-takip cihazı kullanarak tespit etmeye çalışmışlardır. Katılımcılara aynı anda sunulan 2 farklı piyango seçeneğinden tercih yapmaları talep edilen çalışmada oyunun tamamlanmasını takiben katıımcılara 15 Euro ödeme yapıımıştır. Çalışmanın bulguları göz odaklanmasının (fixation) tercih edilen oyuna doğru kaydığı (bais olduğu), katılımcıların oyun olasılıkları ve para miktarlarına odaklandıkları, özellikle de olumsuz sonuçlar aldıklarında tercih edilmeyen oyunun getirisine odaklandıkları bulunmuştur. 


\section{VERI VE YÖNTEM}

Katılımcılardan Windows 10 işletim sisteminde iMotions(c) programı kullanılarak hazırlanan ve 1280x1024 çözünürlükte bir ekran üzerinde kendilerine yöneltilen soruları cevaplandırmaları istenmiştir. Katılımcıların bilgisayar ekranından $60 \mathrm{~cm}$ uzağa oturmaları sağlanmış ve her katılımcının anket sorularını cevaplamaya başlaması öncesinde dokuz noktalı kalibrasyon yöntemi kullanılarak göz takip cihazının ayarlaması yapılmıştır. Ayarlama işlemi bittikten sonra katılımcılar anket sorularını cevaplamaya başlamışlardır. Katılımcıların soruları cevaplama süresince göz bebeği hareketleri EyeTribe isimli araç (göz takip cihazı) ile kaydedilmiştir.

Katılımcılara yöneltilen anket dört farklı bölümden oluşmaktadır. Birinci bölümde yöneltilen soruların amacı katılımcıların "Risk Algısı"nı ölçmektir. Risk algısı ölçümü için üç senaryo oluşturulmuştur. Senaryoların hepsinde katılımcıların bir miktar garanti para ile \%50 ihtimalle garanti paranın daha üzerinde bir miktar para kazanma şansı (şans oyunu) arasında tercih yapmaları istenmiştir. Katılımcının şans oyunu oynamayı tercih etmesi ve oyunu kaybetmesi durumunda ise herhangi bir garanti para ödemesi olmayacaktır. Söz konusu üç senaryoda temel işleyiş aynı olmakla beraber, katılımcılara teklif edilen garanti para ve şans oyunu sonrası kazanma olasılığı olan para miktarları değişmektedir. Birinci senaryoda katılımcılara \%50 ihtimalle 300 TL kazanma şansı veren bir oyun (kazanmaları durumunda $300 \mathrm{TL}$, kaybetmeleri durumunda ise $0 \mathrm{TL}$ ) ile sırasıyla 8 farklı garanti para arasında tercih yapmaları istenmiştir. Örneğin, birinci senaryonun ilk aşamasında katılımcıya hiç garanti para teklif edilmemiş (garanti para OTL) ve \%50 ihtimalle 300 TL kazanma şansı veren oyunu oynama hususundaki kararı sorulmuştur. İinci aşamada ise katılımcıya 30 TL garanti para veya \%50 ihtimalle 300 TL kazanma şansı veren oyunu oynama hususundaki kararı sorulmuştur. Dolayısıla, ilk veya ikinci aşamada katılımcı şans oyunu oynamayı tercih edebilir (kazanırsa 300 TL alır, kaybederse 0 TL alacaktır) veya hiç oyun oynamadan 30 TL'yi (ikinci aşamada) tercih edebilir. İkinci senaryoda yukarıda anılan parasal değerler 10 ile, üçüncü senaryoda ise 100 ile çarpılarak katılımcıların, yine, garanti para ile \%50 ihtimal ile garanti paranın daha üzerinde bir miktar para kazanma şansı arasındaki tercihleri sorulmuştur. Oluşturulan senaryolar kapsamında katılımcılara önerilen garanti para ve şans oyunu sonrası kazanabilecekleri para miktarları Tablo 1'de gösterilmektedir.

Tablo 1: Garanti Para ve Şans Oyunu Beklenen Getiri

\begin{tabular}{|c|c|c|c|c|}
\hline & Aşama & $\begin{array}{c}\text { Teklif Edilen Garanti } \\
\text { Para Miktarı (TL) }\end{array}$ & $\begin{array}{c}\text { \%50 İhtimalle Kazanılabilecek } \\
\text { Para Miktarı (TL) }\end{array}$ & $\begin{array}{l}\text { Şans Oyununun Tercih Edilmesi } \\
\text { Durumunda Beklenen Getiri (TL) }\end{array}$ \\
\hline \multirow{8}{*}{ Senaryo 1} & 1 & 0 & \multirow{8}{*}{300} & \multirow{8}{*}{150} \\
\hline & 2 & 30 & & \\
\hline & 3 & 60 & & \\
\hline & 4 & 100 & & \\
\hline & 5 & 130 & & \\
\hline & 6 & 150 & & \\
\hline & 7 & 170 & & \\
\hline & 8 & 200 & & \\
\hline \multirow{8}{*}{ Senaryo 2} & 1 & 0 & \multirow{8}{*}{3.000} & \multirow{8}{*}{1.500} \\
\hline & 2 & 300 & & \\
\hline & 3 & 600 & & \\
\hline & 4 & 1.000 & & \\
\hline & 5 & 1.300 & & \\
\hline & 6 & 1.500 & & \\
\hline & 7 & 1.700 & & \\
\hline & 8 & 2.000 & & \\
\hline \multirow{8}{*}{ Senaryo 3} & 1 & 0 & \multirow{8}{*}{30.000} & \multirow{8}{*}{15.000} \\
\hline & 2 & 3.000 & & \\
\hline & 3 & 6.000 & & \\
\hline & 4 & 10.000 & & \\
\hline & 5 & 13.000 & & \\
\hline & 6 & 15.000 & & \\
\hline & 7 & 17.000 & & \\
\hline & 8 & 20.000 & & \\
\hline
\end{tabular}

Tablo 1'de gösterildiği üzere her bir senaryoda katılımcılara 8 farklı tutarda garanti para (her bir senaryo 8 aşama) teklif edilmiştir. Böylelikle, farklı miktarlardaki garanti para teklifleri karşısında verdikleri kararlar doğrultusunda katılımcıların risk alma davranışları analiz edilmeye çalışılmıştır. Farklı senaryolarda garanti para ve şans oyunu sonucu kazanılabilecek para miktarlarının 
değiştirilmesi de katılımcıların kararlarının teklif edilen para miktarı ile değişip değişmediğini ortaya koyacaktır. Katılımcılar verdikleri kararlar doğrultusunda 3 grup altında sınıflandııılmıştır. Bir katılımcının bir senaryo altında 0. ila 5. aşama arasında şans oyunu oynamak yerine garanti parayı tercih etmesi, ilgili katılımcının risk almayı sevmeyen bir risk algısına sahip olduğu şeklinde yorumlanmıştır. Çünkü 0'dan 5. aşamaya kadar olan aşamalarda (5. aşama dahil) teklif edilen garanti para miktarı, şans oyununun beklenen getirisinden düşüktür. Diğer taraftan, 7. ve 8. aşamalara kadar şans oyununu oynamayı tercih eden katılımcılar ise risk seven olarak sınıflandırılmışlardır. Bunun sebebi ise 6 . aşamadan sonra şans oyununun beklenen getirisinin teklif edilen garanti para miktarının altında olmasıdır. 6. aşamada teklif edilen garanti para miktarı ile şans oyunun beklenen getirisi eşittir, dolaysıyla 6. aşamada şans oyunu oynamayı tercih etmeyen katılımcılar risk doğal olarak sınıflandırılmıştır. Tablo 2'de katılımcıların risk algısının sınıflandırılma kriterini özetlemektedir.

Tablo 2: Risk Algısı Sınıflaması

\begin{tabular}{lcc}
\hline & $\begin{array}{c}\text { Şans Oyunu Oynamama Kararı Verilme } \\
\text { Aşamasında }\end{array}$ & Katılımcı Sınıflaması \\
\hline \multirow{2}{*}{ Eğer } & Beklenen Getiri > Garanti Para & Risk Sevmeyen \\
\cline { 2 - 3 } & Beklenen Getiri = Garanti Para & Risk Doğal \\
\hline
\end{tabular}

Bu bölümün başında da değinildiği gibi katılımcılara 4 kısımdan oluşan bir anket yöneltilmiştir. Anketin birinci bölümü yukarıda anlatıldığı üzere katılımcının risk algısını tespit etmeye yöneliktir. Anketin ikinci bölümü ise katılımcıların, finansal okur-yazarlık seviyelerinin tespit edilmesi için OECD INFE (2011) tarafından önerilen, 7 sorudan oluşan enflasyon, basit ve bileşik faiz gibi sorulardan oluşmaktadır. Katılımcıların bu bölümde verdikleri her doğru cevap " 1 ", her yanlış cevap ise " 0 " olacak şekilde puanlanmış ve puanlar toplanarak katılımcıların finansal okur-yazarlık puanları hesaplanmıştır.

Anketin üçüncü bölümünde Atkinson ve Messy (2012) tarafından önerilen 8 sorudan oluşan beşli Likert ölçeği kullanılarak katılımcıların finansal davranış ve finansal tutum puanları hesaplanmıştır. Katılımcıların anket sorularına verdikleri cevaplardan "hiç katılmıyorum" cevabı " 1 ", "çok katılıyorum" cevabı ise " 5 " olacak şekilde kodlanmış ve ortamalası alınarak finansal tutum ve davranış puanı hesaplanmıştır.

Ankette yer alan dördüncü ve aynı zamanda son bölümde ise katılımcıların demografik değişkenler cinsiyet, yaş, sınıf ve aylık gelir bilgileri toplanmıştır.

\section{BULGULAR}

Çalışmaya 41 öğrenci katılmış, bunlar arasından 39 öğrencinin verileri geçerli olduğundan analizler 39 öğrenci üzerinden yapılmıştır. Çalışmaya katılan öğrencilerin 21'i (\%54) kadın 18'i (\%46) erkektir. Çalışmaya katılan öğrenciler; 28 tanesi 2 ile 4 sınıf öğrencilerinden, 9 tanesi yüksek lisans öğrencilerinden ve 2 tanesi doktora eğitimi yapan öğrencilerden oluşmaktadır. Çalışmaya katılan öğrencilerin yaş aralığı 19 ile 38 arasında değişmektedir. Öğrencilerin gelir durumları \%10,3 (4 kişi) 500 TL den az geliri olan, \%28,3 (11 kişi) 501 ile 1.000 TL arasında, \%46,2 (18 kişi) 1.001 ile 3.000 TL arasında ve \%15,4 (6 kişi) 3.000 TL den fazla olarak değişmektedir.

Senaryolara göre öğrencilerin risk algısının frekans dağılımı Tablo3 'de verilmiştir. Tablodan da anlaşılacağı gibi senaryolardaki garanti para miktarı arttıkça katılımcıların risk almama eğilimi artmaktadır. Birinci senaryoda katılımcıların sadece \%28,2 risk almamayı tercih ederken, ikinci senaryo da bu oran \%56,4'e çıkmış, üçüncü senaryoda ise bu oran \%61,5 olmuştur.

Tablo 3: Öğrencilerin Senaryolara Göre Risk AlgıSı

\begin{tabular}{lllllll}
\hline & \multicolumn{2}{l}{ Senaryo 1 } & \multicolumn{2}{l}{ Senaryo 2 } & \multicolumn{2}{l}{ Senaryo 3 } \\
\hline Risk Almayan & 11 & $\% 28,2$ & 22 & $\% 56,4$ & 24 & $\% 61,5$ \\
\hline Risk Doğal & 15 & $\% 38,5$ & 10 & $\% 25,6$ & 12 & $\% 30,8$ \\
\hline Risk Seven & 13 & $\% 23,3$ & 7 & $\% 17,9$ & 3 & $\% 7,7$ \\
\hline TOPLAM & 39 & $\% 90$ & 39 & $\% 99$ & 39 & $\% 100$ \\
\hline
\end{tabular}

Katılımcıların cinsiyet ve senaryolar için risk algıları çapraz tablolar kullanılarak incelenmiş ve Tablo 3'deki sonuçlar elde edilmiştir. Senaryo 1 ve senaryo 2 kapsamında risk almayan veya risk seven kadınların sayısı, erkeklerin sayısından fazladır. Aynı iki senaryoda risk doğal olarak tanımlanan erkeklerin sayısı ise kadınların sayısından fazladır. Senaryo 3 de ise bu durum tersine dönmekte, risk almayan veya risk seven erkeklerin sayısı, kadınların sayısından, risk doğal kadın sayısı ise erkek sayısından fazladır. 
Tablo 4: Öğrencilerin Senaryolara ve Cinsiyetlerine Göre Risk AlgıSı

\begin{tabular}{lcccccc}
\hline & \multicolumn{2}{c}{ Senaryo 1 } & \multicolumn{2}{c}{ Senaryo 2 } & \multicolumn{2}{c}{ Senaryo 3 } \\
\hline & Kadın & Erkek & Kadın & Erkek & Kadın & Erkek \\
\hline Risk Almayan & $6(\% 54,6)$ & $5(\% 45,5)$ & $13(\% 59,1)$ & $9(\% 40,9)$ & $11(\% 45,8)$ & $13(\% 54,2)$ \\
\hline Risk Doğal & $7(\% 46,7)$ & $8(\% 53,3)$ & $3(\% 30)$ & $7(\% 70)$ & $9(\% 75)$ & $3(\% 25)$ \\
\hline Risk Seven & $8(\% 61,5)$ & $5(\% 38,5)$ & $5(\% 71,4)$ & $2(\% 28,6)$ & $1(\% 33,3)$ & $2(\% 66,7)$ \\
\hline
\end{tabular}

Senaryolar arasında ödül farklılı̆ının, katılımcıların risk algısını değiştirip değiştirmediğini anlamak için Ki kare bağımsızlık testi yapılmıştır. Ki kare bağımsızlık sınamasında beklenen değerlerin 5'den küçük olması durumunda Fisher's Testi sonuçlarına bakılması istatistiksel olarak doğru olacağından, Fisher's Testi, test istatistiği olarak kullanılmıştır. Tablo 5'de senaryoların Ki kare bağımsızlığı test istatistikleri ve p değerleri verilmiştir. Katılımcıların risk algısının senaryolardan bağımsız olduğu hipotezi reddedilememiştir. Dolayısıyla, katılımcıların risk algısı, senaryolardan etkilenmemekte ve şans oyunundaki ödül miktarı değişirken katılımcıların risk algısı değişmemektedir.

Tablo 5: Senaryoların Bağımsızlık Testi Sonuçları

\begin{tabular}{lcc}
\hline & Fisher's test istatistiği & p-değeri \\
\hline Senaryo 1 -Senaryo 2 & 7,349 & 0,111 \\
\hline Senaryo 1 -Senaryo 3 & 2,085 & 0,844 \\
\hline Senaryo 2 -Senaryo 3 & 4,825 & 0,278 \\
\hline
\end{tabular}

Katılımcıların şans oyunu ile garanti para arasında tercihlerindeki değişikliklerin parasal ödül miktarından etkilenip etkilenmediğinin tespiti için bağımlı örneklerde parametrik olmayan İşaret (Sign Test) testi yapılmıştır. Katılımcıların her bir oyunda tercihlerinin medyan değerleri karşılaştırması yapılmış ve test istatistikleri ile $p$ değerleri Tablo 6 'da verilmiştir.

Tablo 6: Senaryolara Göre Yapılan Tercihlerin Karşılaştırılması

\begin{tabular}{lcc}
\hline & İşaret Testi Z değeri & p-değeri \\
\hline Senaryo 2 Oyun - Senaryo 1 Oyun & $-2,514$ & 0,012 \\
\hline Senaryo 3 Oyun - Senaryo 2 Oyun & $-3,482$ & 0,000 \\
\hline Senaryo 3 Oyun - Senaryo 1 Oyun & $-2,739$ & 0,006 \\
\hline Senaryo 2 Garanti Para - Senaryo 1 Garanti Para & $-2,157$ & 0,031 \\
\hline Senaryo 3 Garanti Para - Senaryo 2 Garanti Para & $-2,835$ & 0,005 \\
\hline Senaryo 3 Garanti Para - Senaryo 1 Garanti Para & $-2,547$ & 0,014 \\
\hline
\end{tabular}

Katılımcıların her bir oyunda 8 aşamada garanti para ya da oyun arasında tercih yapması istenmişti. Katılımcılara üç senaryoda garanti para miktarı arttırılarak teklifte bulunulmuş ve oyun ile garanti para arasında seçim yapmaları istenmiştir. Her bir katılımcı için oyunda yaptığı garanti paraya geçme sıraları arasında fark olup olmadığı işaret sıra testi ile karşılaştırılmıştır.

Tablo 6'daki bulgular katılımcıların garanti para miktarının artması durumunda şans oyunu oynamaktan daha erken vazgeçtiklerini, diğer bir ifade ile garanti parayı almaya daha erken karar verdiklerini istatistiksel olarak göstermektedir. Tablo 5 ve Tablo 6'daki sonuçlar karşılaştırıldığında katılımcıların risk algısının senaryoya göre farklılaşmadığı ancak şans oyunu ile garanti para arasında yapacakları tercihlerde daha erken bir aşamada garanti parayı tercih ettiklerini göstermektedir.

Katılımcıların risk kategorileri ile ekrandaki seçeneklere bakma süreleri, finansal okuryazarlıkları, finansal tutumları ve finansal davranışları Mann-Whitney U Testi ile karşılaştırılmıştır. Aşağıda, sadece anlamlı farklılık olanlar grupların test istatsitkleri ve $p$ değerleri verilmiştir.

Senaryo 1 için Risk Almayan ve Risk Doğal bireylerin Senaryo 1 için oyunu sonlandırdıkları seçeneğe bakma sürelerinin Risk Almayan bireylerde daha fazla olduğu bulunmuştur. Senaryo 1 için Risk Seven ve Risk Doğal bireylerin Senaryo 1 için oyunu sonlandırdıkları seçeneğe bakma sürelerinin Risk Seven bireylerde daha fazla olduğu bulunmuştur. Senaryo 2 için Risk Almayan ve Risk Seven bireylerin Senaryo 2 için garanti para seçeneğine bakma sürelerinin Risk Almayan bireylerde daha fazla olduğu bulunmuştur. 
Tablo 7: Bakma Süreleri

\begin{tabular}{|c|c|c|c|c|c|c|}
\hline & Kategori & $\mathbf{N}$ & Sıra Ortalaması & Mann-Whitney U & $\mathbf{Z}$ & p-değeri \\
\hline \multirow{2}{*}{$\begin{array}{l}\text { Senaryo } 1 \text { Oyun Sonlandırma } \\
\text { Seçeneğinde Gözün Bekleme Süresi }\end{array}$} & Risk Almayan & 10 & 14,80 & \multirow[b]{2}{*}{7,00} & \multirow[b]{2}{*}{$-3,252$} & \multirow[b]{2}{*}{0,000} \\
\hline & Risk Doğal & 10 & 6,20 & & & \\
\hline \multirow{2}{*}{$\begin{array}{l}\text { Senaryo } 1 \text { Oyun Sonlandırma } \\
\text { Seçeneğinde Gözün Bekleme Süresi }\end{array}$} & Risk Doğal & 10 & 6,80 & \multirow{2}{*}{13,000} & \multirow[b]{2}{*}{$-2,403$} & \multirow[b]{2}{*}{0,016} \\
\hline & Risk Seven & 8 & 12,88 & & & \\
\hline \multirow{2}{*}{$\begin{array}{l}\text { Senaryo } 2 \text { Garanti Para } \\
\text { seçeneğinde Gözün Bekleme Süresi }\end{array}$} & Risk Almayan & 18 & 11,44 & \multirow{2}{*}{1,00} & \multirow{2}{*}{$-2,145$} & \multirow{2}{*}{0,021} \\
\hline & Risk Seven & 2 & 2,00 & & & \\
\hline
\end{tabular}

Kadın ve erkek katılımcıların finansal tutum, finansal davranış ve finansal okuryazarlık puanları Mann-Whitney U Testi ile karşılaştırılmıştır. Erkeklerin kadınlara göre finansal okuryazarlıklarının daha fazla olduğu tespit edilmiş. Finansal tutum ve finansal davranışlarda bir farklııı olmadığı tespit edilmiştir. Benzer karşılaştırma senaryolar bazında her bir kategorideki bireylerin finansal tutum, finansal davranış ve finansal okuryazarlık puanları içinde yapılmış ancak farklılık olmadığı tespit edilmiştir.

Tablo 8: Finansal Okur-Yazarlık

\begin{tabular}{llrrrrr}
\hline & Kategori & N & Sıra Ortalaması & Mann-Whitney U & Z & p-değeri \\
\hline \multirow{2}{*}{ Finansal Okuryazarlık puanı } & Kadın & 21 & 15,69 & \multirow{2}{*}{98,50} & \multirow{2}{*}{$-2,658$} & 0,010 \\
\cline { 2 - 4 } & Erkek & 18 & 25,03 & & & \\
\hline
\end{tabular}

\section{SONUÇ}

Herhangi bir konuda karar verirken, konuya ilişkin bilgilerin nasıl işlendiği, karar aşamasında çeşitli hesaplamaların yapılıp yapılmadığı, risk ve belirsizlik durumlarında karar sürecinin nasıl şekillendiği, karar verme süreçlerindeki demografik, fiziksel ve biyolojik faktörlerin neler olduğu ve yanıt bekleyen daha birçok soru uzun yıllardır araştırmacıları meşgul etmektedir. Teknolojik gelişmeler, hala bir kara kutu olan karar verme süreçlerinin anlaşılmasında ise az da olsa araştırmacılara ışık tutar niteliktedir.

Bu çalışmada bir grup üniversite öğrencisinin risk altında karar verme davranışları göz takip cihazı ve anket yöntemi kullanılarak incelenmiştir. Bulgular kadınların erkeklere nazaran daha az risk almayı tercih ettiklerini, farklı senaryolar altında katılımcıların risk algılarının değişmediği ancak garanti para miktarı arttıkça oyunun erken aşamalarında garanti para tercihi yaptıklarını göstermiştir. Göz takip cihazı ile yapılan incelemelerde katılımcıların risk kategorileri ile ekrandaki seçeneklere bakma süreleri, finansal okuryazarlıkları, finansal tutumları ve finansal davranışları karşılaştırılmıştır. Bulgular farklı risk algısına sahip katılımcıların tercih ettikleri oyuna bakma ve garanti para seçeneğine bakma sürelerinin farklı olduğunu göstermiştir. Senaryolar bazında her bir kategorideki bireylerin finansal tutum, finansal davranış ve finansal okuryazarlık puanları ikili karşılaştırmaya tabi tutulmuş ve farklılık olmadığı tespit edilmiştir.

\section{REFERANSLAR}

Atkinson, A., \& Messy, F.-A. (2012). Measuring Financial Literacy: Results of the OECD/ International Network on Financial Education (INFE) Pilot Study (No. 15). OECD Publishing: OECD Working Papers on Finance, Insurance and Private Pensions. http://dx.doi.org/10.1787/5k9csfs90fr4-en

Bault, N., Wydoodt, P., \& Coricelli, G. (2016). Different Attentional Patterns for Regret and Disappointment: An Eye-tracking Study. Journal of Behavioral Decision Making, 29(2-3), 194-205. https://doi.org/10.1002/bdm.1938

Berg, J., Dickhaut, J. \& McCabe, K. (1995). Trust, reciprocity, and social history. Games Econ. Behav. 10, 122-142.

Crosetto P. \& Filippin A. (2016). A theoretical and experimental appraisal of four risk elicitation methods. Experimental Econonomics, 19, 613641.

Deck C., Lee J., Reyes J.A. \& Rosen C.C. (2013). A failed attempt to explain within subject variation in risk taking behavior using domain specific risk attitudes. Journal of Economic Behavior \& Organization, 87, 1- 24.

Dohmen, T., Falk, A., Huffman, D., Sunde, U., Schupp, J. \& Wagner, G.G. (2011). Individual risk attitudes: measurement, determinants and behavioral conse-quences. Journal of the European Economic Association, 9, 522-550.

Dohmen T., Falk A., Huffman D. \& Uwe Sunde U. (2010). Are risk aversion and impatience related to cognitive ability?. American Economic Review, 100, 1238-1260. 
Dreber, A. \& Hoffman, M. (2007). 2D: 4D and Risk Aversion: Evidence that the Gender Gap in Preferences is Partly Biological. Manuscript, Stockholm School of Economics.

Dreber, A., Rand, D., Garcia, J., Wernerfelt, N., Lum, J. \& Zeckhauser, R. (2010). Dopamine and Risk Preferences in Different Domains. Harvard University, John F. Kennedy School of Government (Working Paper Series, rwp10-012).

Fiedler, S., \& Glöckner, A. (2012). The dynamics of decision making in risky choice: An eye-tracking analysis. Frontiers in Psychology. https://doi.org/10.3389/fpsyg.2012.00335

Franco-Watkins, A. M., \& Johnson, J. G. (2011). Applying the decision moving window to risky choice: Comparison of eye-tracking and mousetracing methods. In Judgment and Decision Making (Vol. 6).

Glöckner, A., \& Herbold, A. K. (2011). An eye-tracking study on information processing in risky decisions: Evidence for compensatory strategies based on automatic processes. Journal of Behavioral Decision Making, 24, 71-98. https://doi.org/10.1002/bdm.684

Harrison G.W., Lau M.I. \& Rutström E. E. (2007). Estimating risk attitudes in Denmark: A field experiment. Scandinavian Journal of Economics, 109(2), 341-368.

Holt, C.A. \& Laury, S.K. (2002). Risk aversion and incentive effects. American Economic Review, 95, 902-904.

Holt, C. A., \& Laury, S. K. (2014). Assessment and estimation of risk preferences. Handbook of the Economics of Risk and Uncertainty, 1, 135201. https://doi.org/10.1016/B978-0-444-53685-3.00004-0

Krajbich, I., Armel, C., \& Rangel, A. (2010). Visual fixations and the computation and comparison of value in simple choice. Nature Neuroscience, 13(10), 1292-1298. https://doi.org/10.1038/nn.2635

Lönnqvist J.E., Verkasalo M., Walkowitz G. \& Wichardt P. C. (2015). Measuring individual risk attitudes in the lab: Task or ask? An empirical comparison. Journal of Economic Behavior \& Organization, 119, 254-266.

OECD INFE (2011). Measuring financial literacy: core questionnaire in measuring financial literacy: questionnaire and guidance notes for conducting an internationally comparable survey of financial literacy.

Oran, J. S., \& Akyatan, A. (2012). A pilot study for measuring correlations between hormone levels and risk taking in men and women at different times of day. International Journal of Behavioural Accounting and Finance, 3(3/4), 202. https://doi.org/10.1504/ijbaf.2012.052177

Orquin, J. L., \& Mueller Loose, S. (2013). Attention and choice: A review on eye movements in decision making. Acta Psychologica, 144(1), 190206. https://doi.org/10.1016/j.actpsy.2013.06.003

Sarin R. \& Wieland A. (2016). Risk aversion for decisions under uncertainty: Are there gender differences ? Journal of Behavioral and Experimental Economics, 60, 1-8.

Stewart, N., Hermens, F., \& Matthews, W. J. (2016). Eye Movements in Risky Choice. Journal of Behavioral Decision Making, 29(2-3), 116-136. https://doi.org/10.1002/bdm.1854

Sutter M., Kocher m. G., Glätzle-Rützler D., \& Trautmann S. T. (2013). Impatience and uncertainty: experimental decisions predict adolescents' field behavior. American Economic Review, 103(1), 510-531.

Vieider, F. M., Lefebvre, M., Bouchouicha, R., Chmura, T., Hakimov, R., Krawczyk, M., \& Martinsson, P. (2015). Common components of risk and uncertainty attitudes across contexts and domains: Evidence from 30 countries. Journal of the European Economic Association, 13(3), 421-452. https://doi.org/10.1111/jeea.12102 